\title{
PENDIDIKAN HUMANIS DALAM KELUARGA
}

\section{(Konstruksi Pola Asuh Orang Tua dalam Mempersiapkan Generasi Masa Depan)}

\author{
Mira Mareta ${ }^{1}$
}

\begin{abstract}
Abstrak: Keluarga sebagai lembaga pendidikan tertua memiliki peran utama dalam pembentukan karakter anak, maka dibutuhkan keterampilan orang tua dalam proses pengasuhan dan pendidikan dalam keluarga. Oleh karenanya mendidik anak merupakan kerja sepanjang usia orang tua yang membutuhkan bekal pengetahuan dan pemahaman yang sangat komplek. Selain kedekatan (hubungan emosional) antar anggota keluarga, adaptabilitas (proses berbagi peran dalam keluarga), dan komunikasi antar anggota keluarga menentukan keberhasilan dalam proses pengasuhan, ternyata mendidik anak juga tidak dapat dilepaskan dari aspek pemahaman agama orang tua, karena pemahaman agama memberikan gambaran bagaimana orang tua mendefiniskan tentang anak, dunia anak hari ini, dan dunia di masa depannya. Kompleksitas persoalan kemanusiaan menuntut perlunya kontruksi pola asuh orang tua yang humanis, sehingga melahirkan anak yang memiliki komitmen kuat atau kesetiaan terhadap kemanusiaan di era digital.
\end{abstract}

Key word: Pola Asuh orang tua, pendidikan keluarga, pendidikan humanis.

\section{PENDAHULUAN}

Pola asuh orang tua selalu menjadi sorotan dan pembahasan yang tak pernah ada habisnya bila dikaitkan dengan pendidikan dan masa depan anak. Perhatian tentang pola asuh orang tua menguat karena menjadi pemicu sekaligus problem solver terhadap dampak modernisasi. Bafadal mengidentifikasi tiga persoalan yang besar yang dianggap sebagai krisis di era globalisasi yaitu: 1) munculnya situasi ketiadaan norma sosial (social normlessness), 2) tumbuh suburnya fenomena kenakalan dan kriminalitas, dan 3) kelunturan rasa nasionalisme. ${ }^{2}$ Situasi social normlessness ditandai dengan lunturnya kaidah normatif, baik norma hukum positif, norma agama, maupun tradisi

1 Dosen pada Fakultas Tarbiyah dan Ilmu Keguruan Universitas Islam Negeri (UIN) Mataram.

2 Fadhlm AR Bafadal, Pemuda dan Pergumulan Nilai Pada Era Global, (Jakarta: Balitbang Agama dan Diklat Keagamaan, 2003), 53. 
sopan santun yang dianut masyarakat. Sementara kenakalan dan kriminalitas sudah tak mengenal usia, anak usia sekolah dasarpun dapat terdampak dan telah banyak contohnya. Demikian juga lunturnya jiwa nasionalisme menyebabkan terjadinya kesenjangan budaya, dimana budaya luar lebih cepat diserap daripada budaya luhur bangsa Indonesia.

Keluarga sebagai lembaga pendidikan tertua memiliki peran utama dalam pembentukan karakter anak, maka dibutuhkan keterampilan orang tua dalam proses pengasuhan dan pendidikan dalam keluarga. Modal bagi orang tua yang paling utama adalah harus memiliki seperangkat pengetahuan dan pemahaman tentang perkembangan anak, sehingga orang tua mampu menggali potensi dan mengembangkannya secara optimal dan menyeluruh sesuai dengan norma-norma dan nilai-nilai kehidupan yang dianut meliputi aspek fisik, intelektual, sosial, emosi, moral dan agama. ${ }^{3}$

Perkembangan adalah serangkaian perubahan progresif yang terjadi akibat dari proses kematangan dan pengalaman, seperti dikatakan oleh Van den Dalk, perkembangan berarti perkembangan secara kualitatif. Ini berarti bahwa perkembangan bukan hanya sekadar perubahan beberapa sentimeter pada tinggi badan seseorang atau peningkatan kemampuan seseorang, melainkan suatu proses integrasi dari banyak struktur dan fungsi yang kompleks. ${ }^{4}$ Dan untuk memantapkan dan menyempurnakan perkembangan potensi yang dibawanya sejak lahir, anak memerlukan pengembangan melalui pemeliharaan atau pengasuhan dan pembiasaan atau latihan.

\section{Pola Pengasuhan Orang tua : Kedekatan, Adaptabilitas, dan Komunikasi dalam Keluarga}

Orang tua dalam pengasuhan memiliki beberapa definisi yaitu ibu, ayah, atau seseorang yang akan membimbing dalam kehidupan baru, seorang penjaga, maupun seorang pelindung. Orang tua adalah seseorang yang mendampingi dan membimbing semua tahapan pertumbuhan anak, yang merawat, melindungi, mengarahkan kehidupan baru anak dalam setiap tahapan perkembangannya.

Maka pola asuh dapat diartikan sebagai proses interaksi total antara orang tua dan anak, yang mencakup proses pemeliharaan (pemberian makan, membersihkan dan melindungi) dan proses sosialisasi (mengajarkan perilaku yang umum dan sesuai dengan aturan dalam masyarakat. Proses ini melibatkan juga bagaimana orang tua

3 Eti Nurhayati, Psikologi Pendidikan Inovatif, (Yogyakarta, Pustaka Pelajar, 2011), hlm 4.

4 Elizabeth B. Hurlock, Development Psychology, Fifh Edition, alih bahasa Istiwidayanti, Psikologi Perkembangan; Suatu Pendekatan Sepanjang Rentang Kehidupan, (Jakarta: Erlangga, cet.VI, 1997), hlm. 2. 
mengkomunikasikan afeksi, nilai, minat, perilaku dan kepercayaan kepada anakanaknya. ${ }^{5}$ Albert Bandura menegaskan dalam teorinya teori kognitif sosialnya (Social Cognitive theory), perilaku dibentuk dan berubah melalui interaksi dengan orang lain. Pembentukan dan pengubahannya dilakukan melalui observasi dengan model atau contoh, hasil perilaku dengan individu lain, tertama individu yang dapat dijadikan contoh atau model (orang tua maupun guru) akan dijadikan penguat dari luar (vicarious reinforcement), bahkan mungkin menjadi acuan dalam membentuk penguat dari dalam (internal reinformcement) atau (self reinforcement), yang dikenal dengan observational learning theory atau social learning theory.

Sebagai sebuah sistem sosial, keluarga dapat dianggap sebagai sebuah konstelasi dari subsistem-subsistem berdasarkan generasi, gender, dan peran. Pembagian tugas di antara anggota keluarga menentukan beberapa sub unit tertentu dan kelekatan menentukan hal lainnya. Mengutip pendapat dari Minuchin dalam Santrock, setiap anggota keluarga merupakan partisipan di dalam beberapa subsistem-subsistem dyadic (melibatkan dua orang), seperti ayah dan anaknya atau ibu dan ayah, dan subsistem polyadic (melibatkan lebih dari dua orang), seperti ibu, ayah, anak, atau ibu dan dua saudara kandung. ${ }^{6}$

Maka relasi di dalam keluarga sangat menentukan bagaimana pola pengasuhan terbentuk, karena di dalamnya memuat interaksi antar individu dalam keluarga. Interaksi tersebut ada yang mempengaruhi secara langsung maupun tidak langsung kepada perkembangan anak. Misalnya, pola asuh yang terjadi ketika anggota keluarga yang hanya ada ibu atau ayah saja (anak tinggal dengan salah satunya), maka anggota keluarga di dalamnya akan mengalami perubahan peran yang signifikan. Itulah mengapa bahwa relasi perkawinan, pola asuh orang tua sangat berkaitan erat dengan perilaku dan perkembangan anak. Temuan yang paling konsisten adalah bahwa orang tua yang perkawinannya bahagia cenderung lebih sensitif, responsif, hangat, dan afektif terhadap anak-anaknya.

Menurut Santrock, gaya atau pola pengasuhan anak ada 4 klasifikasi: ${ }^{7}$ pertama, pola asuh permissif indifferent (permissive-indifferent/uninvolved, dalam pola penngasuhan ini, kontrol atau pengawasan orang tua rendah, begitu juga derajat interaksi orang dengan anak rendah, serta kehangatan orang tua terhadap anak juga rendah. Orangtua cenderung menunjukkan jarak, sikap kurang simpatik, sikap pasif, mengabaikan emosi anak, tetapi tetap menyediakan kebutuhan dasar mereka. Dengan pola pengasuhan seperti tersebut di atas dapat mengakibatkan self esteem anak kurang

5 Kompas, Minggu, 28 Februari 2016.

6 John W. Santrock, Remaja, Jilid II, edisi kesebelas, alih bahasa Benedictine Widyasinta, (Jakarta: Erlangga, 2007), 6 .

7 Ibid, 15. 
berkembang, cenderung immature, kurang perhatian, terhambat penyesuaian dirinya, spontan tetapi berani mencoba.

Kedua, pola asuh permissif indulgent (permissive indulgent): Orangtua menunjukkkan kehangatan yang tinggi tetapi kontrol yang rendah terhadap perilaku anak. Orangtua sangat terlibat dengan kehidupan anak, cenderung bersikap lunak dan minim arahan, aturan tidak jelas, anak cenderung menjadi "bos". Orang tua yang memanjakan membiarkan anaknya melakukan apapun yang mereka inginkan. Hal tersebut menyebabkan anak tidak pernah belajar mengendalikan perilakunya sendiri dan berharap agar kemauannya didikuti. Akibat lebuh jauh lagi anak menjadi manja, kurang dewasa, kurang teratur, egois, mudah menyerah, tidak disiplin., dan anak anak memiliki keterbatasan dalam kompetensi sosialnya, khususnya yang menyangkut pengendalian diri.

Ketiga, pola asuh otoriter (authoritarian parenting): kontrol orang tua tinggi terhadap perilaku anak, tetapi rendah dalam kehangatan. Orangtua cenderung berperan sebagai "bos", menuntut ketaatan, bersikap kaku, penuh aturan. Orang tua otoritarian menetapkan batasan-batasan dan kendali yang tegas terhadap anak dan kurang memberikan peluang kepada anak untuk berdialog secara verbal dan cenderung mengedepankan hukuman.

Anak yang dibesarkan oleh orang tua yang otoritarian sering kali cemas terhadap perbandingan sosial, kurang memperlihatkan inisiatif, dan memiliki keterampilan komunikasi yang buruk. Akibatnya, kepribadian anak yang terbentuk adalah mudah cemas, kurang percaya diri, kurang komunikasi, sulit untuk membuat keputusan, cenderung memberontak, mudah sedih dan tertekan, tetapi di sisi lain bisa membentuk perilaku disiplin, mandiri, tanggung jawab dan idealis.

Keempat, pola asuh otoritatif (authoritative parenting): orangtua cenderung menunjukkan adanya kontrol dan kehangatan yang tinggi terhadap anak. Di dalamnya terdapat aturan, sikap asertif, dukungan, fleksibilitas, serta self regulation sehingga anak bebas berkreasi dan mengeksploitasi berbagai hal dengan sensor batasan dan pengawasan orangtua. Orang tua dengan gaya otoritatif memberikan kesempatan kepada anak-anaknya untuk berdialog secara verbal. Kepribadian anak yang terbentuk adalah ceria, menyenangkan, kreatif, cerdas, percaya diri, terbuka pada orang tua, tidak mudah stress dan depresi, berprestasi baik. 
Gambar 1.1. Skema Rangkap Empat dari Gaya Pengasuhan Orang Tua

\begin{tabular}{|l|l|l|}
\hline \multicolumn{1}{|c|}{ Sikap } & \multicolumn{1}{|c|}{$\begin{array}{c}\text { Menerima, responsif, } \\
\text { terpusat pada anak }\end{array}$} & $\begin{array}{c}\text { Menolak, tidak } \\
\text { responsif, terpusat pada } \\
\text { orang tua }\end{array}$ \\
\hline Menuntut, mengendalikan & $\begin{array}{l}\text { Otoritatif yang bersifat } \\
\text { timbal balik, komunikasi } \\
\text { dua arah }\end{array}$ & $\begin{array}{l}\text { Otoritarian, memperlihatkan } \\
\text { kekuasaan }\end{array}$ \\
\hline $\begin{array}{l}\text { Tidak menuntut, usaha untuk } \\
\text { mengendalikan rendah }\end{array}$ & Memanjakan & $\begin{array}{l}\text { Melalaikan, mengabaikan, } \\
\text { tidak peduli, tidak terlibat }\end{array}$ \\
\hline
\end{tabular}

Memperhatikan skema keempat gaya pengasuhan, orang tua mengendalikan keempat gaya tersebut diatas, tetapi dapat dipastikan ada kecenderungan gaya pengasuhan yang dominan mempengaruhi perilaku atau perkembangan anak. Dari keempat gaya tersebut orang tua harusnya dapat memilih gaya otoritatif yang lebih efektif digunakan dalam membantu perkembangan anak secara optimal, baik dari segi fisik motorik, kognitif, bahasa, emosi, sosial, moral dan agamanya. Berikut alasan mengapa gaya pengasuhan orang tua yang otoritatif merupakan gaya yang paling efektif: 1) orang tua otoritatif mencapai keseimbangan yang baik antara pengendalian dan otonomi, memberikan peluang kepada anak-anak untuk mengembangkan kemandirian sambil memberikan standar, batasan, dan bimbingan yang diperlukan, 2) orang tua otoritatif cenderung lebih banyak melibatkan anakanaknya dalam dialog verbal dan membiarkan mereka mengekspresikan pandanganpandangannya. Jenis diskusi dalam keluarga inilah yang dapat membantu anak-anak dalam memahami relasi sosial dan hal-hal yang dibutuhkan untuk menjadi seorang pribadi yang kompeten, 3) kehangatan dan keterlibatan yang diberikan oleh orang tua membuat anak lebih bersedia menerima pendidikan orang tua.

Gaya pengasuhan akan mempengaruhi bagaimana kedekatan antar keluarga, proses adaptasi antar anggota keluarga dan komunikasi yang dibangun dalam keluarga.

1. Dimensi kedekatan keluarga (cohesion) menunjukkan sejauh mana anggota keluarga dapat terpisahkan atau terhubungkan secara emosional dengan keluarganya. Kedekatan ini akan melibatkan beberapa hal penting dalam keluarga, seperti ikatan emosional (emotionalbonding), keterlibatan dalam keluarga (family involvement), digambarkan sebagai banyaknya interaksi yang terjadi dan seperti apa kecenderungan mereka berespon dengan kasih sayang, hubungan orang tua dan anak (parent-child relation) mencakup kedekatan dan batas-batas 
dalam keluarga, dan batas-Batas (boundaries), batas internal (waktu, ruang, dan pengambilan keputusan), batas eksternal (teman, minat, rekreasi).

Bagi orang tua otoritatif, kedekatan antar anggota keluarga tentunya akan banyak diwarnai dorongan ingin melakukan diskusi dan bertukar pikiran, sehingga mampu mendekatkan diri dan terhubung untuk saling memahami

2. Dimensi adaptabilitas keluarga (adaptability), kemampuan sistem keluarga untuk mengubah struktur kekuasaan, aturan dalam menjalin relasi, dan aturan dalam merespon situasi dan perkembangan stress. Dalam proses adaptabilitas dalam keluarga sangat ditentukan oleh struktur kekuasaan dalam keluarga, yaitu kepemimpinan (leadership), kontrol (control), dan negosiasi (negotiation) dalam keluarga. Gaya pengasuhan yang dianut oleh keluarga akan menjelaskan bagaimana negoisasi yang terjadi antar anggota keluarga dalam menentukan serta melaksanakan aturan-aturan yang berlaku dalam keluarga, misalnya mengenai peran dan menjalankan aturan bersama. Maka adaptabilitas keluarga akan memunculkan empat tingkatan yang berbeda untuk masing-masing gaya pengasuhan, ada yang kaku (rigid), terstruktur (structured), fleksibel (flexible), dan kacau (chaotic).

3. Dimensi Komunikasi (Communication); faktor yang berperan dalam proses negosiasi pada keluarga yang sedang mengalami perubahan akibat perkembangan ataupun pertumbuhan anggotanya. Dalam komunikasi keluarga harus memperhatikan aspek-aspek keterampilan mendengar (listening skills), keterampilan berbicara (speaking skills), keterbukaan diri (self disclousure), kejelasan (clarity), berkesinambungan (continuity tracking), respek (respect), dan adanya rasa hormat (regard). Apabila komunikasi dalam keluarga berlangsung baik, maka akan tercipta keterbukaan antar anggota keluarga dalam berkomunikasi, kebebasan atau kelancaran pertukaran informasi, dan adanya pengertian dan kepuasan dalam berinteraksi. Sedangkan kalau komunikasi berlangsung buruk, maka memunculkan banyak permasalahan dalam komunikasi antar keluarga, keengganan untuk saling berbagi antar anggota keluarga dengan cara interaksi yang negatif.

\section{Konstruksi Pola Asuh Orang Tua Sebagai Upaya Mempersiapkan Generasi Berkualitas}

\section{Tantangan Modernitas Di Era Digital}

Istilah modernisasi selalu disandingkan dengan industrialisasi, meski kedua istilah tersebut sebenarnya memiliki makna, proses, fungsi dan peranan yang berbeda. 
Di beberapa negara maju, salah satu penyebab modernisasi adalah tumbuhnya industrialisasi, tetapi di beberapa negara lainnya, modernisasi merupakan penyebab dari industrialisasi. Oleh karena itu, baik modernisasi maupun industrialisasi keduanya menyangkut pertumbuhan ekonomi. akan tetapi modernisasi lebih inklusif dibandingkan industrialisasi, karena modernisasi dapat terjadi di berbagai sektor kehidupan manusia. Modernisasi ditandai dengan adanya perubahan yang terjadi pada manusia, baik secara individu, kelompok, atau struktur sosial. ${ }^{8}$

Modernisasi memiliki makna yang selalu mengisyaratkan kepada suatu nilai yang serba positif yaitu "canggih", ke"maju"an atau ke"kini"an. Dengan makna tersebut maka modernisasi selalu dihubungkan dengan istilah ilmu pengetahuan dan teknologi (iptek) yang selalu berubah dan mengalami kemajuan. Sebagai dampak dari modernisasi, saat ini dunia telah menjadi era serba digital, dimana jaringan internet saat ini seperti senjata bermata dua, satu sisi memberikan manfaat, individu bisa belajar dan mencari informasi sampai berkomunikasi melalui media sosial (instagram, facebook, twitter, line, dll) yang memungkinkan terjadinya interaksi sosial di dunia virtual, sehingga bisa berbagi informasi dengan cepat dan mudah dengan tanpa dibebani batas, jarak, dan waktu.

Hari ini media sosial telah menggantikan kanal informasi mainstream,seperti surat kabar lokal maupun nasional. Media sosial telah menjadi sumber informasi alternatif yang dipercaya tanpa dilakukan proses verifikasi dan konfirmasi, padahal kerap sekali penyebaran informasi yang tidak benar, boax fitnah, ghibah, gosip, pemutarbalikan fakta, ujaran kebencian, permusuhan, kesimpangsiuran, informasi palsu, yang mendorong disharmoni sosial bertebaran secara liar di media sosial. Media sosial juga memunculkan gejala meningkatnya perilaku keberagamaan yang ekstrim antara lain kecenderungan mengkafirkan pihak lain (takfiri). Di kalangan umat Islam terdapat kelompok yang suka menghakimi, menanamkan kebencian, dan melakukan tindakan kekerasan terhadap kelompok lain dengan tuduhan sesat, kafir, dan liberal. Konflik ideologi yang ramai diperbincangkan akhir-akhir di Indonesia tidak dapat dipungkiri menjadikan media massa dan sosial menjadi wadah pergesekan wacana mengenai Islam dan kebangsaan. Probematika yang muncul hampir merusak tatanan nilai pada semua aspek kehidupan, seperti aspek ekonomi, aspek sosial budaya, dan aspek sosial keagamaan

2. Lima Generasi dalam 100 (Seratus) Tahun

Setiap dekade akan memunculkan karakteristik generasi yang mencerminkan zamannya. Perkembangan teknologi yang berjalan cepat, dan seiring berjalannya

8 Eti Nurhayati, Psikologi..., 312. 
waktu, terbentuk satu generasi baru yang tentu saja memiliki pola pikir dan karakter yang berbeda dari generasi sebelumnya, dengan sejumlah faktor pendukung membentuk kepribadian bahkan paradigma tersendiri untuk mencerminkan setiap generasi. Satu generasi menggambarkan keadaan atau situasi di mana setiap individu mempunyai pengalaman hidup yang tersendiri. Ia juga menggambarkan siapa diri kita dan bagaimana kita melihat dunia dari kacamata sendiri. Karl Mannheim mendefinisikan bahwa generasi merupakan kumpulan individu yang memiliki rentang usia serta memiliki pengalaman mengikuti peristiwa penting yang terjadi dalam sejarah.

Lynn Lancaster dan David Stillman mempertegas bahwa setiap generasi mempunyai kepercayaan, nilai, budaya, perspektif, kegemaran, kemahiran dan kepribadian yang berbeda terhadap kehidupan dan pekerjaan. Walaupun terdapat perbedaan atau jurang antara ciri-ciri bagi setiap generasi, namun ia bukanlah penghalang untuk mencapai keterpaduan antara generasi untuk mencapai kebahagiaan dan kesuksesan bersama. Berikut periodesasi generasi menurut Lynn Lancaster dan David Stillman: ${ }^{9}$

a. Baby Boomers (Lahir Pada 1946 - 1964)

Sebelumgenerasi baby boomers, ada satu generasi yaitu generasi pre baby boomer yang lahir tahun 1945 dan sebelumnya dimana perang tengah bergejolak. Adapun generasi baby boomers terlahir pada masa dimana berbagai perang telah berakhir, sehingga perlu penataan ulang kehidupan dan banyak keluarga yang memiliki banyak anak. Di samping itu, perekonomian dan pertumbuhan penduduk sedang mulai meningkat. Adat istiadat masih dipegang teguh dan bahasa slank belum berkembang. Orang-orang pada masa itu masih cenderung "kolot" dan sangat matang dalam pengambilan keputusan.

Pandangan akan pekerjaan dan kehidupan pribadi para Baby Boomers tidak seimbang, dimana generasi ini menganggap bahwa hidup untuk bekerja. Namun demikian, loyalitas dan dedikasi dalam bekerja menjadi poin positif bagi Baby Boomers. Generasi Baby Boomers saat ini sedang menikmati masa-masa-masa pensiun,

b. Generasi X (Tahun Kelahiran 1965-1979)

Generasi ini cenderung suka akan risiko dan pengambilan keputusan yang matang akibat dari pola asuh dari generasi sebelumnya, Baby Boomers. Generasi ini terlahir pada masa-masa adanya gejolak dan transisi serta menyaksikan berbagai konflik global seperti Perang Dingin, Perang Vietnam, jatuhnya Tembok Berlin.

9 Yanuar Surya Putra, Theoritical Review : Teori Perbedaan Generasi, dalam Journal Among Makarti, Vol. 9. No. 18, Desember, 2016, 125. 
Generasi ini cenderung lebih toleran, menerima berbagai perbedaan yang ada. Selain itu, dari segi teknologi informasi, generasi ini mulai mengenal yang namanya komputer sehingga generasi ini mulai berpikir secara inovatif untuk mempermudah kehidupan manusia.

c. Generasi Y / Generasi Millennial (Tahun Kelahiran 1980-1994)

Di era ini, selain komputer sudah menjamur, ditambah lagi dengan berkembangnya videogames, gadget, smartphones dan setiap kemudahan akan fasilitas berbasis komputer (computerized) yang ditawarkan serta kecanggihan internet, membuat Generasi Y menjadi suatu generasi yang mudah mendapatkan informasi secara cepat. Pola pikir dan karakter generasi ini dapat dikatakan generasi penuh ideide visioner \& inovatif untuk melahirkan generasi yang memiliki pengetahuan dan penguasaan IPTEK.

d. Generasi Z (Tahun Kelahiran 1995 - 2012)

Generasi ini adalah peralihan dari Generasi Y dimana teknologi sedang berkembang. Pola pikir mereka cenderung serba ingin instan. Namun masih belum banyak yang dapat disimpulkan karena usia mereka saat ini masih menginjak remaja. Kehidupan mereka cenderung bergantung pada teknologi, mementingkan popularitas dari media sosial yang digunakan.

\section{e. Generasi Alpha (Tahun Kelahiran 2012 - Sekarang)}

Generasi ini adalah lanjutan dari generasi Z dimana mereka sudah terlahir dengan teknologi yang semakin berkembang pesat. Di usia mereka yang sangat dini, mereka sudah mengenal dan sudah berpengalaman dengan gadget, smartphone dan kecanggihan teknologi yang ada. Selain itu, kebanyakan mereka terlahir dari keluarga dengan masa Generasi Y yang juga terlahir pada masa-masa awal perkembangan teknologi. Pola pikir mereka yang terbuka dengan perkembangan serta transformatif dan juga inovatif akan mempengaruhi perkembangan anak-anak generasi Alpha.

Pada hari ini yang disebut sebagai anak berada pada periode generasi $\mathrm{Z}$ dan Alpha, yaitu yang memiliki rentang usia antara $0-23$ tahun. Oleh karena itu perlu diuraikan bagaimana karakteristik kedua generasi ini, agar bisa ditemukan pola pengasuhan yang praktis untuk menghantarkan anak menyambut hari ini, dan masa depannya. Sedangkan yang sekarang disebut sebagai orang tua yang memiliki anak pada generasi $Z$ dan Alpha adalah orang tua yang berada pada periode generasi $\mathrm{X}$ dan Y, yaitu yang berusia antara $24-53$ tahun. 


\section{Menemukan Pola Pengasuhan Orang Tua di Era Digital}

Sebagaimana dijelaskan di atas, bahwa anak pada hari ini merupakan periode generasi $Z$ dan Alpha yang hidup di era digital. Maka penting mencoba mencari konstruksi pola pengasuhan agar anak dapat survive dan memiliki masa depannya. Generasi X (sebagai orang tua) dulu tumbuh dengan orang tua yang sangat terfokus menembus struktur kaku dalam diri mereka, lebih sedikit melewatkan waktu bersama ibu/ayah, dibandingkan dengan generasi sebelumnya. Apabila diibaratakan dalam siuasi saat itu generasi $\mathrm{X}$ adalah generasi pertama yang membawa kunci rumah sendiri dan sekolah pulang ke rumah yang kosong, mereka menyusun jadwal sendiri dan menyiapkan makan sendiri, mereka beradaptasi dengan orangtua yang bekerja. Pada saat itu juga telah muncul teknologi.

Pola asuh orang tua yang diberikan kepada generasi $\mathrm{X}$ mempengaruhi bagaimana generasi X mendidik generasi $\mathrm{Z}$ maupun Alpha. Orang tua generasi X lebih cenderung sebagai orang tua yang menjadi sarang bagi anaknya, memastikan mereka lebih banyak bersama keluarga dan anak-anak gen $\mathrm{Z}$ mereka tidak terlalu sering ditinggalkan di rumah sebagaimana mereka dulu. Di samping itu orangtua generasi X mementingkan kualitas dan kuantitas waktu bersama keluarga, bahkan teknologi telah mengubah cara menerapkan pola asuh, kini semakin banyak aplikasi dan alat untuk mengetahui keberadaan anak-anak serta apa yang mereka lakukan sepanjang waktu.

Pengalaman generasi $\mathrm{X}$ diasuh oleh orang tua yang sering meninggalkan mereka, maka generasi $\mathrm{X}$ sebagai orang tua berusaha membangun ikatan yang special dengan anak-anaknya. Sementara untuk penggunaan teknologi orang tua generasi $\mathrm{X}$ merasa nyaman dengan sebagaimana anak-anak $\mathrm{Z}$ menggunakannya. Sepanjang sejarah baru kali ini ada banyak kesamaan antara orangtua dan anak, mulai dari selera musik, pakaian sampai aktivitas yang dijalani. Namun perlu diingat meski orang tua generasi X mudah terhubung ke internet, bukan berarti mereka selalu tahu segalanya, berbeda dengan anak-anak mereka generasi $Z$ tangkas dalam memahami cara menyembunyikan segala sesuatu dai orangtua mereka. Dapat disimpulkan Gen $\mathrm{X}$ dibesarkan dengan TV, medium yang teramat moderat, milenial dibesarkan dengan TV dan internet, dan di masa remaja keduanya sangat moderat, Gen Z dibesarkan dengan ponsel pintar (smartphone) dan aplikasi serta lingkungan yang serba online.

Menurut David dan Jonah, generasi Z memiliki karakteristik figital, hiper kustomisasi, realistis, weconomist, fear of missing out, do it your self, dan kompetitif/ 
terpacu..$^{10}$ Berikut adalah ciri-cirinya dan bagaimana orang tua harus menemukan jalan praktis dalam menghadapi anak-anaknya sesuai dengan karakeristiknya:

a. Figital; Hidup di dunia baru dimana karena kemajuan teknologi yang pesat, penghalang antara fisik dan digital sudah dihilangkan; ketika lahir, Generasi Z melihat dunia dengan segala kemajuan teknologinya. Mereka hidup di dunia baru di mana kemajuan teknologi yang sangat pesat, penghalang antara fisik dan digital sudah dihilangkan. ${ }^{11}$ Generasi $Z$ akan hadir di lingkungan kerja dengan sesuatu hal yang baru dimana tidak terjadi pada generasi sebelumnya. Generasi $Z$ akan memadukan sisi fisik dan digital dengan cara mengkonsumsi, hidup, dan bekerja melalui Skype, Line, Whatsapp.

Dalam kapasitas orang tua untuk menangkal efek negatif dari teknologi, maka orang tua penting untuk mengamati bagaimana anak-anak sisi fisik dan digital dalam kehidupan mereka. Selain itu menjadikan interaksi tatap muka orang tua dan anak mempunyai nilai yang berarti bagi keduanya. Karena semakin di era digital semakin sulit menghadirkan makna dari sebuah interaksi tatap muka.

b. Hiper-kustomisasi; Gen Z mempunyai kemampuan yang tak tertandingi untuk memilih dan mengontrol preferensi mereka, mereka sangatterfokus menciptakan merek individu mereka sendiri sehingga membiarkan identitas mereka lebih terkustominasasi. ${ }^{12}$ Generasi $\mathrm{Z}$ selalu berusaha untuk menyesuaikan identitas mereka dan melakukan kustomisasi agar dikenal dunia. Kemampuan mereka untuk mengustomisasi segala sesuatu menimbulkan ekspektasi bahwa perilaku dan keinginan mereka sudah sangat akrab untuk dapat dipahami.

Sebagai orang tua harus membantu anak-anaknya keluar dari "ruang gema" ciptaan sendiri, dan berikan sudut pandang dan perspektif yang lain, agar anak tidak asyik dengan dunianya sendiri.

c. Realistis; Generasi Z sudah mengalami masa krisis berat sejak dini dimana hal ini membentuk pola pikir pragmatis dalam merencanakan dan mempersiapkan masa depan. Dalam lingkungan kerja, hal ini menciptakan kesenjangan yang cukup lebar antara millennial yang idealis duduk sebagai manajer garis depan. Dengan sifat tersebut, lebih baik selalu bersikap realistis terhadap apa saja yang perlu dilakukan oleh Gen Z untuk bertahan atau bahkan terus maju. ${ }^{13}$

10 David Stillman dan Jonah Stillman, Generasi Z: Memahami Karakter Generasi Baru Yang Akan Mengubah Dunia Kerja, terj. Lina Jusuf, (Jakarta: Gramedia, 2018), xvii. 
Maka sebagai orang tua harus membantu anaknya bicara realistis tentang karier dan kuliah, dan mengarahkan pada karier dengan cara-cara realistis sejak dini dengan mempersiapkannya saat memilihkan Sekolah Menengah Pertama (SMP) dan Sekolah Menengah Atas (SMA). Selain itu orang tua harus terus memotivasi agar anak memiliki pemikiran dan inovasi sambil mengejar pendidikan yang lebih pragmatis, dan ciptakan jalur karier yang terfokus pada pengembangan keterampilan, bukannya hanya gelar dan peringkat.

d. FOMO; Fear Of Missing Out, ketidaksabaran anak muda kini semakin menjadijadi dan dalam banyak hal menjasi sangat serius. Hal ini merupakan sifat yang membedakan generasi $Z$ dengan yang lainnya, mereka memiliki sindrom takut melewatkan sesuatu (sindrom FOMO). Tidak asing lagi mendengar istilah bangun tidur cek telepon genggam untuk update terkini, karena takut sangat takut ketinggalan informasi. Merekapun selalu menjadi yang terdepan dalam trend dan kompetisi, namun, kabar buruknya mereka selalu khawatir jika mereka bergerak kurang cepat dan tidak menuju arah yang benar.

Oleh karena itu orang tua harus waspada dan sensitif terhadap dampak buruk emosional yang ditimbulkan dari FOMO ini, mereka tumbuh di dunia yang terus memupuk rasa iri, merasa ditinggalkan atau tidak layak, kekhawatiran berubah menjadi kecemasan, mengakibatkan anak kurang tidur, depresi, dan terus menerus diingatkan akan kekurangan mereka. Hal inilah yang harus diminimalisir dengan menekankan pada anak-anak, bahwa mereka memiliki potensi dan prestasi di bidangnya masing-masing.

e. Weconomist; Millenial membantu melahirkan ekonomi berbagi, mereka memadukan sifat kolaboratif bawaan dengan dunia teknologi, akhirnya generasi Z menjadi generasi baru weconomist yaitu generasi yang mendayagunakan kekuatan "kami" dalam peran mereka sebagai filantropis.

Memperhatikan gejala ini orang tua harus membekali anak-anak dengan kemampuan "skill sharing" atau berbagi keterampilan dengan yang lain, dengan demikian eksistensi anak diakui dalam lingkungannya.

f. Do It Your Self (DIY); Generasi Z benar-benar generasi do-it-your-self atau melakukan sesuatu sendiri. Mungkin sebagian dari orang tua juga percaya dengan do-it-yourself atau lakukan sendiri dapat mempermudah segala urusan kita lebih cepat dan baik. Sama halnya dengan generasi $Z$ yang tumbuh dengan dunia internet khususnya youtube yang dapat mengajari mereka melakukan apa saja. Gen Z sangat mandiri dan akan berbenturan dengan budaya kolektif yang sebelumnya diperjuangkan oleh generasi Millennials. Generasi Z percaya dengan pernyataan, "Jika ingin melakukannya dengan benar, lakukanlah sendiri". 
Hal tersebut bukanlah hal yang buruk, orang tua hanya perlu membantu anak-anaknya menetapkan mandiri, namun tetap melatih agar tahu dengan kredibilitas dan kapasitas sumber-sumber lain yang mereka temui. Sehingga meskipun mereka meyakini dapat melakukan segala sesuatu sendiri, tapi harus menghormati atau menghargai bahwa ada kekuatan-kekuatan atau kemampuankemampuan yang harus mereka pelajari dari orang lain melalui ineraksi sosial.

g. Terpacu; Generasi Z merasakan tekanan berat serta ketidaksabaran untuk bergerak maju dengan cepat, tak mengherankan Generasi Z adalah generasi yang sangat terpacu (lebih kompetitif). Maka sebagai orang tua harus merangkul dengan kehangatan untuk menyalurkan hasrat berprestasi anak-anaknya. Namun harus dibarengi dengan mendorong anak-anaknya mengakui kesalahan dan membicarakan hikmah yang didapat dari kekalahan. Tidak kalah penting juga adalah melahirkan generasi yang fokus pada kesehatan dan kebugarannya, bimbing mereka tentang cara dan waktu yang tepat untuk berbagi dan berkolaborasi.

\section{Konstruksi Pola Pengasuhan Yang Humanis}

Anak-anak yang rentan terpapar dengan efek negatif dari media sosial sering menyisakan kekhawatiran tersendiri bagi orang tua. Maka penting bagi orang tua untuk melatih anak untuk survive di era digital, yaitu dengan cara : 1) meningkatkan berfikir kritis, anak diarahkan untuk memiliki wawasan, terbuka pada permasalahan yang ada di sekelilingnya (ekonomi, sosial, budaya, politik), sehingga tidak menelan mentah-mentah informasi, senantiasa berfikir kritis dan diajak untuk berfikir memberikan kontribusi terhadap penyelesaian masalah yang ada di lingkungannya, 2) mengajak anak untuk menggunakan media secara bijak. Media sosial bisa menjadi pedang bermata dua, tergantung bagaimana anak menggunakannya, maka perlu kita arahkan untuk menggunakannya dengan bijak, dan hindarkan dari penyebaran informasi tanpa fakta, 3) memupuk jiwa prososial, memikirkan orang lain bukan berarti hanya memperhatikan keluarga kita saja, melainkan konsep masyarakat secara keseluruhan. 4) bantu anak untuk membuat visi hidupnya secara realistis. Hal ini bisa dilakukan dengan membuat visi berbasis SMART (Spesific, Measurable, Acbieveable, Reasonable, dan Time-phased), yaitu visinya spesifik, terukur, bisa dicapai, masuk akal, dan mempunyai tahapan waktunya, sehingga anak bisa memiliki visi yang jelas, dan eksekusinya menjadi sesuatu yang nyata bukanlah sekedar angan atau cita-cita tanpa wujud. Setelah memiliki visi yang jelas, bantulah anak membangun ide dari visi yang telah ditetapkan. Orang tua harus membantu anak memulai meskipun pada hal-hal 
yang kecil, sehingga anak tahu akan proses, kerja keras, dan tanggung jawab pada visinya.

Mencapai keberhasilan dalam menjalankan misi mendidik anak, tidak bisa dilepaskan dengan konsep pengetahuan dan pemahaman keagamaan yang dibangun oleh orang tua. Problematika ini ditemui semakin banyaknya dua sisi/kutub pemahaman agama yang ekstrim, sekuleristik atau radikalistik. Bagi orang tua yang sekuler melepaskan atau memisahkan agama dari aktivitas/rutinitas kehidupan anaknya sehari-hari. Nilai dan norma agama kerap kali dipersepsikan sekedar persoalan akhirat saja. Lambang-lambang keagamaan, lebih jauh, seperti ungkapanungkapan religius, model busana, dan life style lainnya seringkali difungsikan hanya sebagai mode tradisi yang meng-arus (current tradition). Sebagai contoh ketika bulan Ramadhan datang sebagian pemuda baik pria atau wanita menggunakan pakaianpakaian sehari-hari sesuai tuntunan syariat sehingga terlihat anggun dan islami. Namun ketika diluar aktivitas keagamaan,mereka kembali menggunakan pakaian seronok,transparan, vulgar yang tidak sesuai dengan ajaran agama.

Sedangkan orang tua dengan pemahaman radikal, mereka memiliki pemahaman keagamaan yang mengacu pada fondasi agama yang sangat mendasar, fanatik keagamaanya cukup tinggi, tidak jarang penganut paham ini menggunakan kekerasan dalam mengaktualisasikan paham keagamaan yang dianut dan diyakininya. Mereka menginginkan adanya perubahan atau pembaruan sosial-keagamaan secara mendasar dengan sistem atau tata nilai baru yang diyakininya. Islam radikal mengandung makna kelompok Islam yang memiliki keyakinan ideologis tinggi dan fanatik yang mereka perjuangkan untuk menggantikan tatanan nilai dan sistem yang sedang berlangsung, sehingga melahirkan sikap intoleransi.

Kedua model ini pemahaman keagamaan tersebut telah mencerabut Islam dari makna Islam yang rahmatan lil 'alamien. Dari kedua pandangan tersebut, muncul banyak sintesa, antara lainnya adalah pentingnya mengembangkan pendidikan anak diproyeksikan pada "nilai kemanusiaan", karena pada akhirnya seorang anak harus mempertanggungjawabkan segala tindakannya di dalam kehidupan sosialnya. Orang tua dalam mendidik anak terkadang tidak memperhatikan keunikan dan kemandirian peserta didik yang secara pribadi yang harus mempertanggungjawabkan tindakannya, malah justru memasung kreativitas peserta didik, atau dengan istilah lain, mendidik anak dengan cara yang tidak memanusiakan, inilah yang cenderung membuat anak mengalami keterasingan dan kehilangan peneguhan keunikan manusia. ${ }^{14}$

14 John P. Miller, Cerdas di Kelas Sekolah Kepribadian, disadur oleh Dr. Abdul Munir Mulkhan (Yogyakarta: Kreasi Wacana, 2002), 10-12. 
Anak harus dipahami dan dipelajari sebagai keseluruhan yang integral, khas, terorganisir meliputi aspek-aspek dasar dari pribadi yang menyeluruh. ${ }^{15}$ Tidak seperti kaum psikoanalisis yang memusatkan diri pada penyelidikan orang-orang yang mengalami gangguan neorosis dan psikosis, atau kaum behavioris yang memahami dan menerangkan tingkah laku manusia secara terpisah dan elemenistik. Oleh karena itu penting untuk mengupas bagaimana seharusnya pendidikan anak diarahkan agar sesuai dengan kebutuhan dari anak. Adalah teologi-humanistik yang sekiranya dapat memberikan jawaban atas pertanyaan bagaimana seharusnya memandang eksistensi manusia. Dan salah satu tokoh teologi-humanistik adalah Hassan Hanafi, seorang teolog dan filosof dari Mesir. ${ }^{16}$

Teori teologi-humanistik kelahirannya tidak dapat dipisahkan dari sejarah munculnya teori humanism. Humanisme, sebagaimana halnya rekonstruksionisme, menurut skema George R. Knight, merupakan perkembangan dari progresivisme. Fokus perhatian humanism adalah manusia (buman). Aspek ini mesti ada dalam pendidikan, walaupun aliran pemikiran kependidikan memiliki perbedaan persepsi dalam memandang aspek manusianya, mereka tetap memiliki objek yang sama, yaitu manusia. ${ }^{17}$

Struktur pemikiran Hassan Hanafi banyak dipengaruhi dari pengetahuan Barat, ia mengkonsentrasikan diri pada kajian pemikiran Barat pra modern dan modern. Dalam bukunya yang berjudul Qadhaya Mu asyirah 2 : Fi Fikr al-Gharbi al-Mu asir, ia memperkenalkan beberapa pemikiran Barat, seperti Spinoza, Voltaire, Kant, Hegel, Max Weber, Edmund Husser, Unamuno, Karj Jasper dan Herbert Marcuse. ${ }^{18}$

15 Nurhilaliati, Pendidikan Islam dan Psikologi Humanistik Relasi atau Negasi, (Mataram: Alam Tara Isntitut, 2011), 92 .

16 Hassan Hanafi lahir pada lahir pada 13 Pebruari 1935 di Kairo, dekat Benteng Salahudin, daerah perkampungan Al-Azhar. Di masa kecilnya ia berhadapan dengan kenyataan-kenyataan hidup di bawah penjajahan dan dominasi pengaruh bangsa asing. Kenyataan itu membangkitkan sikap patriotik dan nasionalismenya, sehingga tidak heran meskipun masih berusia 13 tahun ia telah mendaftarkan diri untuk menjadi sukarelawan perang melawan Israel pada tahun 1948. Namun Pemuda Muslimin menolaknya karena menganggap bahwa usia Hassan Hanafi masih terlalu muda, selain itu ia juga dianggap bukan berasal dari kelompok Pemuda Muslimin. Sehingg ia kecewa dan segera menyadari bahwa di Mesir saat itu telah terjadi problem persatuan dan perpecahan. Hassan Hanafi merupakan cendekiawan yang sejak semula berbasis pemikiran filsafat. Dalam menyelesaikan studinya pada tahun 1956, ia mendapat gelar sarjana filsafat. Perhatian Hassan Hanafi terhadap filsafat Islam bermula di kampus sebelum berangkat ke Prancis. Di luar kampus ia membaca Hassan al-Banna, Sayyid Quthub, Abul Hassan an-Nadwi, Muhammad al-Ghazali dan pemikir-pemikir muslim kontemporer lainnya.

17 Abd. Rachman Assegaf, Filsafat Pendidikan Islam Paradigma Baru Pendidikan Hadhari Berbasis IntegratifInterkonektif, (Jakarta: Raja Grafindo Persada, Cetakan ke-3, 2014), 212,

18 Kazuo Shimogaki, Kiri Islam : Antara Modernisme dan Postmodernisme : Telaah Kritis atas Pemikiran Hassan Hanafi (Between Modernity and Postmodernity The Islamic Left and Dr. Hassan Hanafis Tought : A Critical Reading) Terj. Jadul Maula \& M. Imam Azis, (Yogyakarta: LKIS, 2000), 3. 
Hassan Hanafi kemudian melakukan reinterpretasi tauhid sebagai counter terhadap liberalism Barat, sosialisme Negara, Marxisme, Tradisional, maupun ritual kesukuan. Menurutnya, ideologi-ideologi modernisasi kontemporer tersebut telah gagal dalam memajukan komunitas muslim. Ia juga mengkritik teologi klasik yang cenderung teosentris, dimana Tuhan menjadi pusat segala kekuatan dan kekuasaan, dan manusia harus tunduk dan ditundukkan. ${ }^{19}$ Hal inilah yang kemudian menjadi pertanyaan apa relevansi teologi teo-sentris untuk menyelesaikan masalah-masalah sosial kemanusiaan.

Pemikiran teologi-humanistik Hassan Hanafi merupakan produk rekonstruksi teologi. Model yang digunakan Hassan Hanafi dalam melakukan rekonstruksi teologi yang tertuang dalam karyanya yang berjudul "Islam In The Modern World: Religion Ideology, and Development. ${ }^{20}$

Hassan Hanafi menegaskan bahwa rekonstruksi teologi tidak harus membawa implikasihilangnyatradisi-tradisilama. Rekonstruksiteologiuntukmengkonfrontasikan ancaman-ancaman baru yang datang ke dunia dengan menggunakan konsep yang terpelihara murni dalam sejarah. Tradisi yang terpelihara itu menentukan lebih banyak lagi pengaktifan untuk dituangkan dalam realitas duniawi yang sekarang. Dialektika harus dilakukan dalam bentuk tindakan-tindakan, bukan hanya terdiri atas konsep-konsep dan argumen-argumen antara individu-individu, melainkan dialektika berbagai masyarakat dan bangsa di antara kepentingan-kepentingan yang bertentangan. Rekonstruksi itu bertujuan untuk mendapatkan keberhasilan duniawi dengan memenuhi harapan-harapan dunia muslim terhadap kemerdekaan, kebebasan, kesamaan sosial, penyatuan kembali identitas, kemajuan dan mobilisasi massa.

Lalu bagaimana mengimplementasikannya dalam mendidik anak dalam keluarga. Pendidikan Agama Islam yang konsep pendidikannya didasarkan pada nilainilai yang diadopsi dari al-Qur'an berkeyaninan bahwa manusia merupakan makhluk yang memiliki kapasitas fisik dan psikis yang memiliki fitrah atau potensi baik, yang dialiri oleh citarasa ketuhanan. Konsep yang berpijak pada al-Asma al-Husna ini membawa konsekuensi bahwa manusia bisa dan diharapkan dapat melakukan sifatsifat seperti yang digambarkan dalam konsep tersebut, meskipun sebatas optimal kemanusiaannya.

19 Menurutnya teologi klasik dalam implementasinya mensubordinasi manusia, ketika dia mengomentari sebuah kitab-kitab ushul al-din karya ulama terdahulu. Dalam kita-kita tersebut selalu diungkapkan puji-pujian terhadap Tuhan dan salam kepada Rasululloh, menurut Hassan Hanafi, puji-pujian kepada Allah dan Rasul-nya merupakan pernyataan kelemahan manusia di hadapan kemaha-besaran-Nya telah menciptakan suatu kondisi psikologis yang tidak mampu mengubah keadaan. Jiwa orang Islam dikerdilkan dan diperlemah dengan selalu menjejelkan dalam kesadaran manusia, ingatan bahwa Dia yang Maha Besar, sementara diri sendiri serba lemah dan membutuhkan pertolongan.

20 Hassan Hanafi, Islam In The Modern World, Ideology, And Development, (Cairo: Daar Kebaa Bookshop, 2000), 12 . 
Konsep pendidikan Islam dipertegas oleh tujuan pendidikan Islam yaitu; "perubahan yang diusahakan oleh proses pendidikan atau usaha pendidikan untuk mencapainya, baik pada tingkah laku individu dan pada kehidupan pribadinya, atau pada kehidupan masyarakat dan pada alam sekitar tentang individu itu hidup, atau pada proses pendidikan sendiri dan proses pengajaran sebagai suatu aktivitas asasi dan sebagai proporsi di antara profesi-profesi asasi dalam masyarakat. ${ }^{21}$

Pencapaian tujuan pendidikan tersebut di atas bukanlah sesuatu yang mudah. Pemikiran Hassan Hanafi setidaknya memberikan konstribusi yang patut dipertahankan dan dicarikan cara implementasinya dalam proses pendidikan anak dalam keluarga. Dari rekonstruksi teologi yang dikemukakan, Hassan Hanafi menelurkan gagasan penafsiran terhadap beberapa sifat-sifat Tuhan yang berangkat dari teosentris menuju antrophomistik humanistik. Hassan Hanafi merumuskan Teologi Humanistik dengan mulai mengartikan tauhid, menurutnya tauhid bukan lagi konsep yang membicarakan tentang keesaan Tuhan yang diarahkan pada faham trinitas maupun politeisme, tetapi lebih merupakan kesatuan pribadi manusia yang jauh dari perilaku dualistic seperti hipokrit, kemunafikan ataupun oportunistik.

Ada beberapa rumusan teologi-humanistik Hassan Hanafi tentang zat dan sifat-sifat Tuhan yang relevan menjadi dasar atau landasan dalam pendidikan Islam. Pertama, konsep wujud, menurut Hassan Hanafi, bahwa tentang wujud Tuhan yang selama ini di tafsirkan oleh para teologi klasik pada ke-Maha-an dan kesucian Tuhan, di artikan oleh Hassan Hanafi menuju " tajribah wujudiyyab" pada manusia, umat manusia di tuntut untuk mampu menunjukkan keberadaannya. Deskripsi Tuhan tentang zat-Nya sendiri memberi pelajaran tentang kesadaran manusia akan dirinya sendiri (cogito), yang secara rasional dapat diketahui melalui perasaan diri (self feeling). Penyebutan Tuhan akan zat-nya sendiri sama persis dengan kesadaran akan keberadaan-Nya, sama sebagaimana cogito yang ada dalam manusia berarti menunjukkan akan keberadaannya.

Dapat digambarkan, bahwa Tuhan sendiri adalah kemerdekaan yang mutlak, akan tetapi kemerdekaan manusia itu walaupun hanya relatif, juga tetap merupakan kemerdekaan, sebagaimana cahaya yang lemah juga cahaya. ${ }^{22}$ Dalam pendidikan ini menandakan bahwa manusia harus memiliki kesadaran akan dirinya dan lingkungannya. Manusia yang merdeka dan bertanggung jawab tidak merupakan mainan di tangan Tuhan yang Maha Kuasa. Kemerdekaan dalam memilih tindakan

21 Omar Mohammad Al-Toumy Al-Syaibani, Falsafah Pendidikan Islam, terj. Dari Falsafah at-Tarbiyyah alIslamiyyah oleh Hasan Langgulung, (Jakarta: Bulan Bintang, 1979), 399.

22 Marcel A. Boisard, Humanisme Dalam Islam, alih bahasa dari L'Humanisme De L'Islam oleh Albin Michel (Jakarta: Bulan Bintang, 1979), 100. 
dan tanggung jawab yang menyertainya memberikan kepada manusia keluhuran dan martabat tinggi serta menegakkan kehidupan moral. ${ }^{23}$

Tentang Qidam (dahulu), diartikan sebagai sebuah pengalaman kesejarahan yang mengacu pada akar-akar keberadaan manusia di dalam proses sejarah. Qidam merupakan akumulasi pengalaman dan pengetahuan kesejarahan untuk digunakan dalam melihat realitas masa depan, sehingga manusia tidak lagi mengulangi kesalahankesalahan, kesesatan, dan taqlid. ${ }^{24}$ Dalam proses mendidik anak, penting bagi orang tua mengamati sejarah, baik dalam melihat potensi dasar anak dalam memberikan stimulasi perkembangan anak.

Baqa' (kekal), merupakan pengalaman kemanusiaan yang muncul dari lawan sifat fana. Baqa' diartikan sebuah tuntunan pada manusia untuk membuat dirinya tidak cepat rusak atau fana, yang bisa dilakukan melalui tindakan konstruktif dalam perbuatan maupun pemikiran, dan menjauhi tindakan-tindakan yang bisa mempercepat kerusakan di bumi. Tujuan pendidikan senyatanya adalah tujuan hidup dan kehidupan manusia, maka dalam menjalani hidup, dituntut melakukan inovasi dan kreativitas agar menemukan kehidupan yang penuh dengan warna dan dinamis, sehingga aura tersebut dapat membantu dirinya sendiri dan orang lain.

Mukhalafah li al-bawadis (berbeda dengan yang lain) dan qiyam binafsib (berdiri sendiri), dari dua sifat ini, manusia di tuntut supaya mampu menunjukkan eksistensinya secara mandiri dan berani tampil beda, tidak mengekor atau taqlid pada pemikiran dan budaya orang lain. Qiyam binafsih adalah deskripsi tentang titik pijak dan gerakan yang dilakukan secara terencana dan dengan penuh kesadaran untuk mencapai sebuah tujuan akhir, sesuai dengan potensi dan segala kemampuan diri. ${ }^{25}$

Dalam psikologi pendidikan ada istilah yang disebut dengan perbedaan individual. Bahwa setiap individu memiliki keunikannya masing-masing, dan pendidikanlah yang bertugas untuk mengembangkannya semua aspek perkembangan secara optimal, baik pada aspek perkembangan kognitif, bahasa, afektif atau emosi, sosial, moral, dan agama.

Wabdaniyah (keesaan), bukan merujuk pada keesaan Tuhan, penyucian Tuhan dari kegandaan (syirik) yang diarahkan pada paham trinitas maupun politeisme, tetapi lebih mengarah eksperimentasi kemanusiaan. Wabdaniyah diartikan sebagai pengalaman umum kemanusiaan tentang kesatuan tujuan, kelas, nasib, tanah air, kebudayaan, dan kemanusiaan. ${ }^{26}$

\footnotetext{
23 Ibid, hlm 101.

24 Hassan Hanafi, Min a-Aqidah...,130-132.

25 Ibid, 137-142

26 Ibid, 309-311.
} 
Al-Ilmu, Al-Qodrat, Al-Hayat, tiga sifat ini dalam pandangan Hassan Hanafi di sebut al-Tsulatsi, menurut dia, sifat Hayat sebenarnya sudah masuk dalam sifat Qodrat, karena suatu zat yang kuasa sudah dipastikan hidup atau Hayat. Akan tetapi bagi Hassan Hanafi tetap menerapkan sifat al-Tsulatsi yang terdiri dari Al-Ilmu, Al-Qodrat, Al-Hayat tanpa menambah atau mengurangi dari ketiga sifat tersebut. Ketika di tulis secara sistematis, maka sifat Al-Ilmu dan Al-Qodrat didahulukan dari Al-Hayat, karena Al-Ilmu dan Al-Qodrat lebih utama dari Al-Hayat. ${ }^{27}$

Pada hakekatnya keberadaannya sifat Al-Ilmu, Al-Qodrat, dan Al-Hayat bukan sifat maknawiyah murni, karena Al-Ilmu membutuhkan Al-Aql (akal) dan Al-Qodrat membutuhkan Al-Iradah dan Al-Hayat membutuhkan hati atau jiwa atau kemerdekaan. Keberadaan sifat tersebut saling ketergantungan, karena $A$ l-Hayat merupakan syarat sifat $A$ l-Ilmu dan Al-Qodrat. Serta tidak ada sifat Al-Ilmu dan Al-Qodrat tanpa sifat AlHayat. Dalam mengartikan ketiga sifat tersebut Hassan Hanafi memberikan makna bahwa Al-Qodrat merupakan sebuah kemerdekaan bagi manusia untuk menggunakan kemampuannya. Untuk Al-Ilmu yaitu bagaimana manusia dapat memanfaatkan karunia yang dimilikinya yaitu akal, sedangkan sifat Al-Hayat merupakan kewajiban manusia untuk selalu berbuat supaya mampu merubah dirinya yang lebih baik.

Al-Sama', Al-Bashor, Al-Kalam, ketiga sifat tersebut bisa di lihat dari keberadaan manusia yang ada dalam wajah atau kepala. Dalam wajah atau kepala manusia ada indra telinga, mata dan mulut. Dan keberadaan telinga, mata, dan mulut tersebut tidak lebih utama dari perasa dan peraba. Dengan demikian menurut Hassan Hanafi bahwa manusia tidak hanya menelan secara mentah-mentah apa yang di lihat, apa yang di dengar dan apa yang diucapkan oleh manusia, tetapi harus mampu mengambil makna secara benar dengan menggunakan sifat yang dimilikinya yaitu peraba dan perasa. Sementara Al-Iradah, merupakan sebuah kemerdekaan bagi manusia dalam beraktifitas dan bergerak dalam menentukan masa depannya, serta untuk menentukan pilihan hidupnya. ${ }^{28}$

Dari gambaran tersebut, penulis memetakan bagaimana pendidikan seharusnya dibangun berdasarkan nilai-nilai teologi-humanistik :

Gambar 1.2. Kontruksi Nilai-Nilai Teologi Humanistik Dalam Pendidikan Anak

\begin{tabular}{|l|l|}
\hline Sifat-Sifat Alloh & \multicolumn{1}{|c|}{ Nilai-Nilai Teologi-Humanistik dalam Pendidikan Anak } \\
\hline Wujud & $\begin{array}{l}\text { Values of freedom and responsibility : Berusaha menempatkan anak } \\
\text { sebagai manusia merdeka dan bertanggung jawab }\end{array}$ \\
\hline
\end{tabular}

27 Ibid, 418-419

28 Ibid, 425-426 


\begin{tabular}{|c|l|}
\hline Qidam & $\begin{array}{l}\text { Values of history : orang tua yang harus memahami pertama } \\
\text { kali potensi yang dibawa anaka sehingga memudahan untuk } \\
\text { memberikan stimulasi. }\end{array}$ \\
\hline Baqaa & $\begin{array}{l}\text { Values of innovation and creativity :Menuntuk adanya inovasi dan } \\
\text { kreativitas dalam pola pengasuhan }\end{array}$ \\
\hline $\begin{array}{l}\text { Mukhalafah li al- } \\
\text { hawadits }\end{array}$ & $\begin{array}{l}\text { Values of uniqueness : menyadari bahwa anak memiliki karakteristik } \\
\text { (perbedaan individual) dan harus memacunya untuk dapat tampil } \\
\text { beda sesuai dengan kemampuan yang dimilikinya. }\end{array}$ \\
\hline Qiyam binafsihi & $\begin{array}{l}\text { Values of vision: orang tua harus memiliki kesadaran penuh untuk } \\
\text { menyusun secara tepat bersama-sama dengan anak-anak visi dan } \\
\text { misi hidupnya. }\end{array}$ \\
\hline Wahdaniyyah & $\begin{array}{l}\text { Values of togetherness : semua proses pendidikan harus ditujukan } \\
\text { kepada kesatuan tujuan kemanusiaan. }\end{array}$ \\
\hline $\begin{array}{l}\text { Qudrah, ilmu, } \\
\text { dan hayat }\end{array}$ & $\begin{array}{l}\text { Values of independency: anak memiliki kemerdekaan untuk } \\
\text { menggunakan kemampuannya, memanfaatkan karunia yang } \\
\text { dimiliki (akal) dan memiliki kewajiban selalu berubah secara } \\
\text { dinamis dan progressif }\end{array}$ \\
\hline Al-sama, bashar, \\
kalam & $\begin{array}{l}\text { Values of development : anak memiliki potensi perkembangan } \\
\text { fisik motorik, sosial, emosi, kognitif, bahasa, moral, dan agama, } \\
\text { sehingga orang tua harus mengembangkan komunikasi, kedekatan } \\
\text { dan proses adaptabiltas yang tepat sesuai dengan potensinya. }\end{array}$ \\
\hline Iradah & $\begin{array}{l}\text { Values of progression: anak diarahkan agar memiliki tujuan hidup } \\
\text { dan bisa senantiasa bergerak maju ke arah yang lebih baik }\end{array}$ \\
\hline
\end{tabular}

Apabila nilai-nilai yang terkandung dalam pendidikan berbasis teologi humanistik, maka akan mendapatkan orang tua yang memiliki perspektif yang baik dalam mengasuh anak yang meliputi; 1) perspektif ideologis; kesalehan tercermin sebagai sebuah kesadaran ilahiyah ,2) perspektif teologis (humanism-inklusif); Islam dimaknai lebih luas sebagai sebuah pembebasan, 3) perspektif antropologis; orang tua memahami budaya, geografis, psikologi, budaya, dan semangat literasi, 4) perspektif teks (divinity and humanity); teks dipahami bukan sekedar tekstual tetapi juga kontekstual, yang menjunjung tinggi nilai-nilai humanistik.

\section{PENUTUP}

Mendidik anak merupakan kerja sepanjang usia orang tua yang membutuhkan bekal pengetahuan dan pemahaman yang sangat komplek. Namun ada satu yang dapat meyakinkan bahwa mendidik anak tidak dapat dilepaskan dari aspek pemahaman agama orang tua. Karena pemahaman agama memberikan gambaran 
bagaimana orang tua mendefiniskan tentang anak dan dunianya, sehingga akan nampak bagaimana orang tua melakukan gaya pengasuhannya.

Dari sekian teori dan implementasi yang disajikan, dapat kita simpulkan bahwa diperlukan pemaknaan yang terus menerus untuk mencari kostruksi pola asuh orang tua, seperti pemikiran teologi humanistik Hassan Hanafi dengan mengajukan konsep baru tentang teologi Islam yang bertujuan menjadikan teologi tidak sekadar sebagai dogma keagamaan yang kosong melainkan menjelma sebagai ilmu tentang perjuangan sosial, menjadikan keimanan berfungsi secara aktual sebagai landasan etik dan motivasi tindakan manusia. Hal ini bisa dijadikan sebagai pondasi oleh orang tua dalam mendidik anak.

Dalam proses pendidikan Islam dalam keluarga, sangat penting mengadopsi pemikiran teologi humanistiknya Hasan Hanafi dalam menyelesaikan permasalahan pada tataran aqidah yang terimplementasi pada nilai-nilai kemanusiaan, ada komitmen kuat atau kesetiaan terhadap kemanusiaan. Artinya teologi humanistik menjadi landasan idelogi pendidikan Islam, sehingga tidak terjadi dikotomi antara aqidah/ tauhid dengan realitas kehidupan yang syarat dengan problematika kemanusiaan terkait dekadensi moral, arus globalisasi yang menyebabkan adanya ketimpangan/ ketidakadilan, kekerasan dan masalah-masalah kemanusiaan lainnya.

Bekal keterampilan teknologi yang dimiliki oleh anak-anak tidak menjadi siasia atau berdampak buruk/negatif bagi perkembangannya, karena orang tua telah memiliki pemahaman teologi yang kuat yang ditanamkan kepada anak-anaknya, bahwa agama adalah kehidupan itu sendiri, bahwa pentingnya menyertakan kehadiranNya dalam setiap aktivitas kehidupan anak Sehingga muncul kesadaran anak yang memiliki kesholehan pribadi sekaligus keshalehan sosial berbasis teologi humanis.

\section{DAFTAR PUSTAKA}

Abd. Rachman Assegaf, Filsafat Pendidikan Islam Paradigma Baru Pendidikan Hadhari Berbasis Integratif-Interkonektif, (Jakarta: Raja Grafindo Persada, Cetakan ke-3, 2014).

Ahmad Hasan Ridwan, Reformasi Intelektual Islam, Pemikiran Hassan Hanafi Tentang Reaktualisasi Tradisi Keilmuan Islam, (Yogyakarta: ITTQA Press, 1998).

David Stillman dan Jonah Stillman, Generasi Z: Memahami Karakter Generasi Baru Yang Akan Mengubah Dunia Kerja, terj. Lina Jusuf, (Jakarta: Gramedia, 2018) 
Hassan Hanafi, Islam In The Modern World, Ideology, And Development, (Cairo: Daar Kebaa Bookshop, 2000).

Hassan Hanafi, Pandangan Agama Tentang Tanah, Suatu Pendekatan Islam, (Yogyakarta: Prisma, 4 April 1984).

Hassan Hanafi, Minal al-Aqidah ila al-Tsaurah, (Kairo: Maktabah Madbuli, 1991).

Elizabeth B. Hurlock, Development Psychology, Fifh Edition, alih bahasa Istiwidayanti, Psikologi Perkembangan; Suatu Pendekatan Sepanjang Rentang Kehidupan, (Jakarta: Erlangga, cet.VI, 1997).

Eti Nurhayati, Psikologi Pendidikan Inovatif, (Yogyakarta, Pustaka Pelajar), 2011

Fadhal AR Bafadal, Pemuda dan Pergumulan Nilai Pada Era Global, (Jakarta: Balitbang Agama dan Diklat Keagamaan, 2003)

John W. Santrock, Remaja, Jilid II, edisi kesebelas, alih bahasa Benedictine Widyasinta, (Jakarta: Erlangga, 2007)

John P. Miller, Cerdas di Kelas Sekolah Kepribadian, disadur oleh Dr. Abdul Munir Mulkhan (Yogyakarta: Kreasi Wacana, 2002).

Kazuo Shimogaki, Kiri Islam : Antara Modernisme dan Postmodernisme : Telaah Kritis atas Pemikiran Hassan Hanafi Between Modernity and Postmodernity The Islamic Left and Dr. Hassan Hanafi's Tought: A Critical Reading) Terj. Jadul Maula \& M. Imam Azis, (Yogyakarta: LKIS, 2000).

Kompas, Minggu, 28 Februari 2016

Muhidin M. Dahlan (ed), Sosialisme Religius Suatu Jalan Keempat?, (Yogyakarta: Kreasi Wacana, 2002).

Marcel A. Boisard, Humanisme Dalam Islam, alih bahasa dari L'Humanisme De L'Islam oleh Albin Michel (Jakarta: Bulan Bintang, 1979).

Nurhilaliati, Pendidikan dan Psikologi Humanistik Relasi atau Negasi, (Mataram: Alam Tara Institut, 2011).

Omar Mohammad Al-Toumy Al-Syaibani, Falsafah Pendidikan Islam, terj. Dari Falsafah at-Tarbiyyah al-Islamiyyah oleh Hasan Langgulung, Jakarta: Bulan Bintang, 1979).

Yanuar Surya Putra, Theoritical Review : Teori Perbedaan Generasi, dalam Journal Among Makarti, Vol. 9. No. 18, Desember, 2016 